\title{
Analysis of the influence of transgenic kalanchoe extract with cecropin P1 on the state of a non-infected wound in rats
}

\author{
Alexandr Belous*, Elena Trubnikova, and Yuri Kljavs \\ Kursk State University, 33, Radishcheva street, Kursk, 305000, Russia
}

\begin{abstract}
In this article data on the analysis of the effect of transgenic Kalanchoe pinnate extract with cecropin P1 on the state of uninfected wounds in rats are presented. The study used Wistar rats weighing $220 \pm 20 \mathrm{~g}$. A wound of $20 \times 20 \mathrm{~mm}$ was modeled under anesthesia in sterile conditions. The wound was treated during 14 days with the $3 \%$ hydrogen peroxide solution in all experimental groups. Additional treatment with the $10 \%$ cefazolin solution was used in group No. 2; with Kalanchoe juice it was used in group No. 3, and with transgenic Kalanchoe extract cecropin P1 it was used in group No. 4. The effectiveness of the treatment of the wound process was evaluated by the external state of the wound and planimetry indicators. It was found that all analyzed parameters of the experimental groups were better than in the control group of animals. However, the effect was most pronounced in the group treated by transgenic Kalanchoe extract with cecropin P1, The results of the study allow us to recommend further preclinical study of the substance for the possible treatment of trophic ulcers in patients with diabetes mellitus.
\end{abstract}

\section{Introduction}

Currently, genetic engineering methods help to synthesize proteins in the cells of various organisms that can be used for therapeutic purposes. In this regard, transgenic plants can be promising objects for the synthesis of recombinant proteins, as well as safe and rather cheap compared to producers of recombinant proteins obtained by the traditional method.

As for the production of transgenic plants, Kalanchoe antimicrobial peptides, there are isolated publications on the transformation of some of these plant species. Effective methods for transforming Kalanchoe are not developed for all species. Transgenic Kalanchoe plants of the species Kalanchöe daigremontiana, K. laciniata, and $K$. blossfeldiana have been obtained [1-3]. The Kalanchoe species K. pinnata (Kalanchoe pinnate) is considered the most valuable for pharmacology.

Cecropin P1 of nematodes belongs to the group of linear $\alpha$-helical peptides, does not correspond to cysteine [4]. Unlike insect cecropins, it consists of one long positively charged $\alpha$-helix; almost all amino acid residues are involved in the formation. Cecropin P1 is highly active against pathogenic gram-negative and gram-positive bacteria, fungi and tumor cells [1, 5-6].

\section{Problem Statement}

In the modern surgery, the treatment of purulent wounds is not a completely solved problem, because the treatment of infected wounds is difficult to treat [7-9]. Purulent complications of wounds, such as endotoxicosis, infectious toxic shock and sepsis, are the cause of an unfavorable outcome in some cases and account for $35-45 \%$, and the mortality rate reaches $25 \%$ [10-12]. Despite the fact that at present there are quite a large number of different methods of therapy for diseases of soft tissues of a purulent-inflammatory nature [13-15], the treatment of wounds under the bandage is the main method, due to the fact that it is easy to use and economically beneficial [16].

One of the modern problems of pharmacotherapy is the uncontrolled use of antibacterial prevention of wound suppuration. Often, antibiotic therapy is empirical in nature, and the selection of an antibiotic, taking into account sensitivity, is delayed for a number of subjective and objective reasons.

\section{Research Questions}

Most often, the microbiological landscape of surgical wounds is represented by staphylococci, streptococci, representatives of the Enterobacteriaceae family, nonfermenting gram-negative bacteria, strict non-sporeforming anaerobic microorganisms. Moreover, in most cases, pathogens are insensitive to many antibacterial drugs $[17,18]$. In addition to pharmacotherapeutic methods, there are also physical methods of antibacterial therapy, in particular, hyperbaric oxygenation, laser, magnetotherapy, controlled abacterial environment, etc. [19]. The disadvantage of the methods is the lack of the possibility of outpatient use of many of them, which reduces the availability for a wide range of patients. As for antiseptic solutions, they are diluted with discharge

\footnotetext{
* Corresponding author: a.s.belous@ mail.ru
} 
from the wound and, therefore, lose their activity within 3-6 hours [20-22]. In this regard, the solution to this problem is a topical issue in modern surgery.

\section{Purpose of the Study}

The purpose of the study was to analyze the effect of transgenic Kalanchoe extract with cecropin P1 on the state of an uninfected wound in rats.

\section{Research methods}

Wounds were simulated on old male and female Wistar rats weighing $220 \pm 20 \mathrm{~g}$. Before the experiment, the animals were quarantined. The rats were kept under standard conditions, which are necessary for this type of study. When carrying out all manipulations with experimental animals, all the principles set forth in the Convention for the Protection of Vertebrate Animals (Strasbourg, 1986) were observed.

The wound was modeled under anesthesia (intraperitoneal injection of chloral hydrate at a dose of $300 \mathrm{mg} / \mathrm{kg}$ ). On the back, an area of about $30 \times 30 \mathrm{~mm}$ was shaved, then this area was treated with an antiseptic and the skin with subcutaneous fat was excised with a size of $20 \times 20 \mathrm{~mm}$. In various experimental groups, in order to prevent drying and deformation of the wound surface, to prevent bites by other rats, as well as to prevent contamination, a sterile gauze bandage was sutured over the wound. After removing the sutures, the gauze bandage was removed and the wound was treated with a 3\% hydrogen peroxide solution.

Subsequently, in all groups of animals, a daily, single treatment of the wound with a $3 \%$ solution of hydrogen peroxide was carried out. In group No. 1, animals that did not receive additional treatment were the control. In group No. 2 (comparison group No. 1), additionally daily, once, the wound surface was treated with Kalanchoe juice. In group No. 3 (comparison group No. 2 ), additionally daily, once, the wound surface was treated with $10 \%$ cefazolin solution. In group No. 4 (test substance), additionally, once daily, the wound surface was treated with an extract of Kalanchoe pinnate leaves with cecropin P1.

The assessment of the course of the wound process in rats was carried out using the following methods: planimetric and by assessing the external state of the wound, i.e. measurement of the time after which the disappearance of perifocal tissue edema, the occurrence of granulations, wound cleansing and the occurrence of marginal epithelization occurred. Further, the calculation of the rate of wound healing was carried out according to the modified method of L.N. Popova. To do this, a transparent film was applied to the wound surface, on top of which a marker was drawn along the contour of the wounds (Fig. 1).

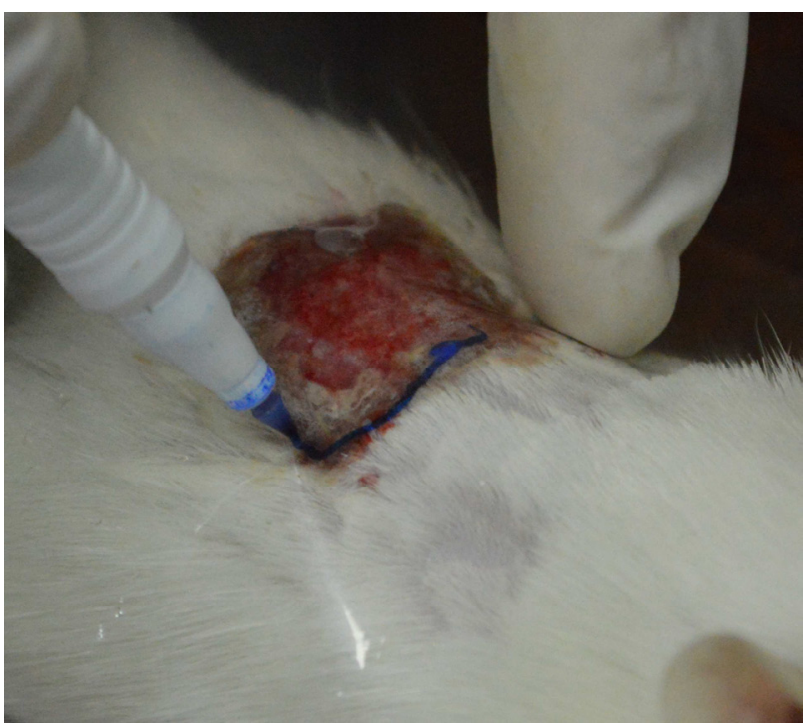

Fig. 1. The external state of the wound on the 3rd day of the experiment. The process of delineating the contour of a wound on a transparent film.

After that, all films were scanned in the Adobe Photoshop program with a resolution of 300 pixels / inch. After the selection of the fragments of the contours of the wounds, the area was calculated using the "Analysis" command. Then, in each group of animals, the average area $(\mathrm{M} \pm \mathrm{m})$ was calculated.

Next, the residual area and the area reduction from the original size expressed as a percentage and the healing rate (area decrease in 1 day expressed as a percentage) were calculated using the formulas:

$$
R A=S / S O \times 100 \%
$$

RA is the residual area of the wound surface, expressed as a percentage (\%),

$\mathrm{S}$ - average area of the wound surface at a certain moment of measurement $\left(\mathrm{mm}^{2}\right)$.

S0 - initial average wound surface area after removal of gauze dressings $\left(\mathrm{mm}^{2}\right)$ :

$$
D A=(S O-S) / S O \times 100 \%
$$

DA is a decrease in the area of the wound surface, expressed as a percentage (\%),

$\mathrm{S}$ is the average area of the wound surface at the moment of measurement $\left(\mathrm{mm}^{2}\right)$.

So - initial average wound surface area after removing gauze dressings $\left(\mathrm{mm}^{2}\right)$ :

$$
R H=(U P 1-U P 0) / T
$$

RH is the rate of wound healing,

DA1 - decrease in the area of the wound surface from the initial at the time of measurement,

DA0 - decrease in the area of the wound surface during the previous measurement,

$\mathrm{T}$ is the number of days between two measurements.

Statistical processing of the research results was carried out according to generally accepted methods for this; the mean value (M) and the error of the arithmetic mean $(\mathrm{m})$ were calculated. To determine the significance of differences between groups of experimental animals, a 
two-sample t-test with different variances was used; the differences were considered statistically significant at $\mathrm{p}$ $<0.05$.

\section{Findings}

On the third day of the experiment, after removing the bandage from the animals before the start of treatment, purulent or purulent-hemorrhagic discharge was not detected in the wound, but there were areas of necrotic tissues and tissue edema in the area of the wound bottom.

During the treatment of wounds, the appearance of the wounds changed: the wounds were cleared of necrotic masses, edema and infiltration of the surrounding tissues were stopped, granulation appeared, and epithelization began. The dynamics of these changes is reflected in table 1 . And the appearance of the wound on days 3,10 and 14 of the experiment is shown in Figures 1-3.

Table 1.1. Criteria for assessing the dynamics of the clinical picture of the wound process.

\begin{tabular}{|c|c|c|}
\hline \multirow{2}{*}{$\begin{array}{c}\text { Experimental } \\
\text { group }\end{array}$} & \multicolumn{2}{|c|}{$\begin{array}{c}\text { Clinical signs of wound } \\
\text { healing }\end{array}$} \\
\cline { 2 - 3 } & $\begin{array}{c}\text { Disappeara } \\
\text { nce of } \\
\text { perifocal } \\
\text { edema, } \\
\text { days }\end{array}$ & $\begin{array}{c}\text { Complete } \\
\text { cleansing of } \\
\text { the wound, } \\
\text { days }\end{array}$ \\
\hline Control & $5.17 \pm 0.31$ & $6.33 \pm 0.33$ \\
\hline Cefazolin & $4.17 \pm 0.17^{*}$ & $5.17 \pm 0.17^{*}$ \\
\hline Kalanchoe & $4.00 \pm 0.00^{*}$ & $4.83 \pm 0.17^{*}$ \\
\hline $\begin{array}{c}\text { Kalanchoe } \\
\text { with cecropin }\end{array}$ & $3.67 \pm 0.21^{*}$ & $4.17 \pm 0.17^{*}$ \\
\hline
\end{tabular}

Table 1.2. Criteria for assessing the dynamics of the clinical picture of the wound process.

\begin{tabular}{|c|c|c|}
\hline \multirow[b]{2}{*}{$\begin{array}{l}\text { Experimental } \\
\text { group }\end{array}$} & \multicolumn{2}{|c|}{ Clinical signs of wound healing } \\
\hline & $\begin{array}{c}\text { The } \\
\text { appearance } \\
\text { of } \\
\text { granulations, } \\
\text { days }\end{array}$ & $\begin{array}{c}\text { Onset of } \\
\text { marginal } \\
\text { epithelializatio } \\
\text { n, days }\end{array}$ \\
\hline Control & $6.50 \pm 0.22$ & $6.50 \pm 0.22$ \\
\hline Cefazolin & $5.50 \pm 0.22 *$ & $5.67 \pm 0.21 *$ \\
\hline Kalanchoe & $5.00 \pm 0.00 *$ & $5.17 \pm 0.17 *$ \\
\hline $\begin{array}{c}\text { Kalanchoe } \\
\text { with cecropin }\end{array}$ & $4.17 \pm 0.17 *$ & $4.33 \pm 0.21 *$ \\
\hline
\end{tabular}

Note: * - in comparison with the control group of animals (if $\mathrm{p}$ $<0.05$ ), $*^{*}$ - in comparison with group No. 3 (if $\mathrm{p}<0.05$ ).

The healing rate and the dynamics of changes in the area of wounds in the groups treated with Kalanchoe juice and transgenic Kalanchoe with cecropin P1 extract was higher than that in the control group of animals. However, the dynamics of changes in the area of wounds and indicators of the rate of wound healing in the group treated by transgenic Kalanchoe extract with cecropin P1 was higher than that in the groups receiving cefazolin and Kalanchoe juice. The dynamics of these changes is reflected in tables 2,3 .

Fig. 2. The external state of the wound on the 10th day of the experiment.

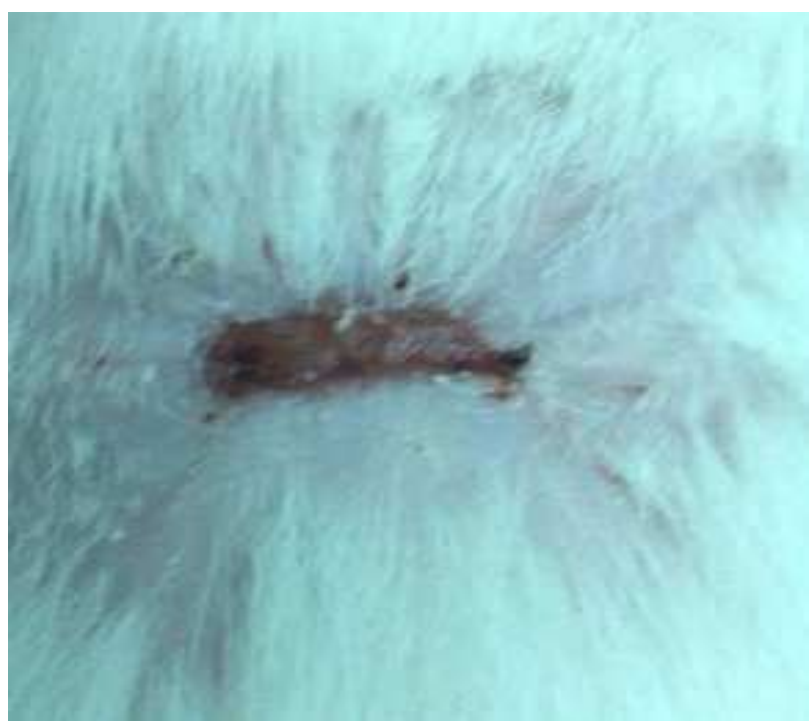

Fig. 3. The external state of the wound on the 14 th day of the experiment.

The processing of the obtained experimental data showed that in all experimental groups the above indicators were better than those in the control group of animals. However, it should be noted that in the group treated with the test substance (Kalanchoe juice with cecropin P1), the effect was most pronounced in comparison with the group treated with cefazolin and Kalanchoe juice.

Experimental wound therapy has shown that the test substance reduces the transition time from the 1st phase of inflammation in the wound to complete regeneration. In comparison with other experimental groups, clinical signs of wound healing appeared earlier. This was also seen in the last stages of wound healing, since in some areas of the wound surface in animals in these experimental groups, a scab was partially preserved. Due 
to the fact that $\mathrm{K}$. pinnata has its own wound healing, immunomodulatory, and remodeling activity [23], this makes it possible to expect an addition as a result of the interaction of the sap of transgenic plants and the antimicrobial component of cecropin P1 to pathogens inside a living organism.

Table 2. The dynamics of changes in the area of the wound surface in rats.

\begin{tabular}{|c|c|c|c|c|}
\hline \multirow{2}{*}{$\begin{array}{l}\text { Experimental } \\
\text { group }\end{array}$} & \multirow{2}{*}{ Indicator } & $\begin{array}{c}3 \\
\text { days }\end{array}$ & 10 days & 14 days \\
\hline & & $n=10$ & $n=7$ & $n=3$ \\
\hline \multirow{3}{*}{ Control } & $\begin{array}{l}\text { S wound } \\
\left(\mathrm{cm}^{2}\right)\end{array}$ & $\begin{array}{l}4.87 \pm \\
0.76\end{array}$ & $\begin{array}{l}2.05 \pm \\
0.67\end{array}$ & $\begin{array}{l}1.32 \pm \\
0.44\end{array}$ \\
\hline & $\mathrm{DA}$ & & $57.98 \%$ & $72.85 \%$ \\
\hline & RA & & $48.84 \%$ & $38.68 \%$ \\
\hline \multirow{3}{*}{ Cefazolin } & $\begin{array}{l}\text { S wound } \\
\left(\mathrm{cm}^{2}\right)\end{array}$ & $\begin{array}{l}4.86 \pm \\
0.64\end{array}$ & $\begin{array}{l}1.87 \pm \\
0.32 \\
\end{array}$ & $\begin{array}{l}1.05 \pm \\
0.21 \\
\end{array}$ \\
\hline & DA & & $61.63 \%$ & $78.35 \% *$ \\
\hline & RA & & $48.37 \%$ & $21.57 \% *$ \\
\hline \multirow{3}{*}{ Kalanchoe } & $\begin{array}{l}\text { S wound } \\
\left(\mathrm{cm}^{2}\right)\end{array}$ & $\begin{array}{l}4.38 \pm \\
0.52\end{array}$ & $\begin{array}{l}1.3 \pm \\
0.42\end{array}$ & $\begin{array}{l}0.61 \\
\pm 0.18\end{array}$ \\
\hline & DA & & $70.46 \% *$ & $86.09 \% *$ \\
\hline & RA & & $18.20 \% *$ & $7.56 \% *$ \\
\hline \multirow{3}{*}{$\begin{array}{l}\text { Kalanchoe with } \\
\text { cecropin }\end{array}$} & $\begin{array}{l}\text { S wound } \\
\left(\mathrm{cm}^{2}\right)\end{array}$ & $\begin{array}{l}5.26 \pm \\
0.28 \\
\end{array}$ & $\begin{array}{l}0.74 \pm \\
0.13 * *\end{array}$ & $\begin{array}{l}0.2 \pm \\
0.01 * *\end{array}$ \\
\hline & DA & & $85.87 \%$ ** & $96.26 \% * *$ \\
\hline & RA & & $14.2 \% * *$ & $3.16 \% * *$ \\
\hline
\end{tabular}

Note: * - in comparison with the control group of animals (if $\mathrm{p}$ $<0.05$ ), $* *$ - in comparison with group No. 3 (if $\mathrm{p}<0.05$ ).

Table 3. Rat wound healing rates in rats.

\begin{tabular}{|c|c|c|}
\hline \multirow{2}{*}{ Experimental group } & \multicolumn{2}{|c|}{$\begin{array}{c}\text { Healing rate } \\
\text { (\%/days) }\end{array}$} \\
\cline { 2 - 3 } & $\mathbf{1 0}$ days & $\mathbf{1 4}$ days \\
\cline { 2 - 3 } & $\mathrm{n}=7$ & $\mathrm{n}=4$ \\
\hline Control & 8.28 & 3.72 \\
\hline Cefazolin & 8.8 & $4.18^{*}$ \\
\hline Kalanchoe & $10.07^{*}$ & 3.91 \\
\hline Kalanchoe with cecropin & $12.27^{*}$ & 2.6 \\
\hline
\end{tabular}

Note: * - in comparison with the control group of animals (if $\mathrm{p}$ $<0.05$ ), $* *$ - in comparison with group No. 3 (if $\mathrm{p}<0.05$ ).

Stimulating immunity by hemagglutinating lectins from K. Pinnata, increase in vascularization and remodel scar tissues by unknown components in Kalanchoe [18] allow accelerating the removal of pathogens from the wound. A positive point is also the antimicrobial effect of cecropin P1, which suppresses the physiological functions of bacteria, which in turn can also lead to an acceleration in the production of antibodies.

\section{Conclusion}

As a result of the experimental study, there was a pronounced efficacy of transgenic Kalanchoe pinnate juice with cecropin P1 on an experimental model of a wound in rats.

This allows us to recommend further preclinical study of the substance. After conducting clinical studies, the use of Kalanchoe leaf extract with cecropin p1 as a drug for the treatment of trophic ulcers in patients with diabetes mellitus is promising.

\section{References}

1. H.M.P. Garces, C.E.M. Champagne, Â. Townsley, S. Park, R. Malho, M.C. Pedroso, J.J. Harada, N.R. Sinha PNAS. 104(39), 15578 (2007)

2. M.R.Trucsdale, O.Toldi, P. Scott Plant Physiol. 121, 957 (1999)

3. M.Sanikhani, H. Mibus, B.M. Stummann, M. Serek Plant Cell Rep. 27, 729 (2008)

4. A. Pillai, S. Ueno, H. Zhang, J.M. Lee, Y. Kato Biochem. J. 390, 207 (2005)

5. E.A. Martemyanov, A.S. Shirin, A.T. Grudkov Biotechnol. Lett. 18(12), 1357 (1996)

6. H.C. Zakharchenko, E.B. Rukavtsova, A.T. Gudkov, A.A. Yukhmanova, L.A. Shkolnaya, K.I. Kado, Ya.I. Buryanov Rep. Acad. Sci. 415(1), 129 (2007)

7. L.A. Blatun. Cons. Med.: Surg. 4, 51 (2011)

8. F.V. Plotnikov. News of Surg. 22(5), 575 (2014)

9. J.S. Carlos. Antimicrob. Agents Chemother. 58, 4353 (2014)

10. I.V. Babushkina. Saratov J. of Med. Sci. Res. 7(2), 530 (2011)

11. N.A. Kuznetsov, V.G. Nikitin. Cons. Med.: Surg. 2, 39 (2006)

12. K. Tanaka. Int. J. Low. Extr. Wounds. 13, 220 (2014)

13. A.S. Belous, A.B. Shevelev, E.V. Trubnikova, Yu.K. Biryukova, E.S. Mishina, E.A. Loiko, A.A. Lebedeva, N.S. Zakharchenko. Bull. Russ. State Med. Univ. 1, 70 (2017)

14. M. De Saint Jean, F. Brignole, A.F. Bringuier, A. Bauchet, G. Feldmann, C. Baudouin. Invest. Ophthalm. Vis. Sci. 40(3), 619 (1999)

15.S. Epstein, M. Ahdoot, E. Marcus, P. Asbell. J. Ocul. Pharmacol. Ther. 25(5), 415 (2009)

16. L. Xiaomeng. J. Bioact. Compat. Polym. 29, 398 (2014) 
17. R.R. Ibragimova, P.A. Kuznetsov. Act. Probl. Mod. Microbial. Immunol. 2, 36 (2017).

18. V.I. Privolnev. Clin. Microbial. and antimicrobial Chemother. 19(2), 131 (2017)

19. S. Acosta, M. Björck, A. Wanhainen. Br. J. Surg. 104(2), e75 (2017)

20.A.E. Bachmanov, A.A. Gridin, Yu.P Kholubkevich. Bull. Voronezh State Technic. Univ. 3(7), 219 (2007)

21. N.S. Kazaryan, K.K. Kozlov, A.Yu. Bykov, S.V. Kokorin, S.I. Viktorov. Bull. Russ. Acad. Med. Sci. 12, 64 (2013)

22. V.K. Okulich, S.D Fedyanin. Bull. Vitebsk St. Med. Univ. 2(4), 30 (2003)

23. T.F. Marinina, L.N. Savchenko, A.S. Saushkina Proc. Samara Sci. Center Russ. Acad. Sci. 17(5) (2015)

24. K. Adenike, O.B. Eretan, Haw. J Biochem Mol Biol. 37(2), 229 (2004) 